${ }^{\circ}$ Entomologica Fennica. 29 November 1996

\title{
Abundance of day-flying Lepidoptera along an air pollution gradient in the northern boreal forest zone ${ }^{1}$
}

\author{
Mikhail V. Kozlov, Alexandr L. Lvovsky \& Kauri Mikkola
}

Kozlov, M. V., Lvovsky, A. L. \& Mikkola, K. 1996: Abundance of day-flying Lepidoptera along an air pollution gradient in the northern boreal forest zone. — Entomol. Fennica 7: 137-144.

Day-active lepidopterans were counted in the summers of 1991-1993 on transects of $5 \times 100 \mathrm{~m}$ in 12 localities representing five zones of pollutioninduced forest deterioration in the Kola Peninsula, northwestern Russia. A total of 671 specimens representing 19 species was observed during 696 counts. Two butterflies (Clossiana euphrosyne, Vacciniina optilete) and three day-active moths (Rheumaptera subhastata, Ematurga atomaria, Sympistis heliophila) were used in the analysis; the remaining 14 butterfly species were too scarce for the statistical treatment. At early stages of pollution-induced forest damage (mean annual $\mathrm{SO}_{2}$ concentrations $20-40 \mu \mathrm{g} / \mathrm{m}^{3}$ ), the densities of the monitored species increased by a factor of 1.5 to 5 , but then declined with increase in pollution. Since the host plants of the monitored species, except that of C. euphrosyne, were found in all localities surveyed, the decline could be attributed to the $\mathrm{SO}_{2}$ toxicity rather than to the lack of larval food. Although transect counts did produce valuable information about the impact of pollution on subarctic forest ecosystems, the method is poorly suited for routine bioindication of pollution in northern regions.

Mikhail V. Kozlov, Laboratory of Ecological Zoology, University of Turku, FIN-20014 Turku, Finland

Alexandr L. Lvovsky, Department of Entomology, Zoological Institute, 199034 St. Petersburg, Russia

Kauri Mikkola, Zoological Museum, P. O. Box 17, FIN-00014 University of Helsinki, Finland

Received 4 January 1995, accepted 8 August 1995

\section{Introduction}

Although butterflies are favourite objects of numerous monitoring programs (Pollard et al. 1986, 1993, Pollard 1991), they have hardly been used as indicators of pollution impact (but see Barbour 1986). However, the large amount of literature on this group, and the simple methods designed for estimating butterfly abundance (Pollard 1977, Hall 1981) make these insects attractive candidates for monitoring of pollution-induced changes in forest ecosystems. Furthermore, the simultaneous counts of day-active moths which can be distinguished in the field by an experienced ob- 
server (Väisänen 1992) can overcome difficulties connected with the low abundance of butterflies in subarctic regions.

Our study aimed to assess changes in the densities of the most abundant butterflies and dayactive moths along an air pollution gradient and to evaluate the suitability of transect counts for a practical monitoring program in the northern boreal forest zone.

\section{Material and methods}

\subsection{Study area and pollution source}

The study was conducted in the largest polluted zone in Northern Europe (about $10000 \mathrm{~km}^{2}$; Kozlov \& Haukioja 1995) around the heavily industrialized city of Monchegorsk (Kola Peninsula, Northwestern Russia; $68^{\circ} \mathrm{N}, 33^{\circ} \mathrm{E}$ ). The region belongs to the northern taiga, $150 \mathrm{~km}$ south of the northern tree limit. About $97 \%$ of the emissions in the Monchegorsk area are produced by the Severonikel smelter complex, which in 1990 emitted 2.33 $\times 10^{8} \mathrm{~kg}$ of sulphur dioxide and $1.58 \times 10^{7} \mathrm{~kg}$ of dusts containing heavy metals $\left(2.7 \times 10^{6} \mathrm{~kg}\right.$ of nickel, $1.8 \times 10^{6} \mathrm{~kg}$ of copper; Berlyand 1991).

\subsection{Sampling sites}

The sampling sites, 23 in total, were chosen at 12 localities (1-13 km N/NE and 1-65 km S/SE of the smelter), representing the mixed spruce-birch forests at different stages of deterioration, as similar in vegetation as possible. Both pre-existing heterogeneity in vegetation structure (Kozlov \& Haukioja 1995) and pollution contributed to the variation in habitat characteristics (Table 1). To account for this variation, the localities were classified as follows:

- Zone 0 . Healthy spruce forest with an admixture of birches (5-10\% of trees); birch seedlings and saplings very sparse; dwarf-shrubs and mosses cover nearly $100 \%$ of the ground; the longevity of spruce needles mainly 10 to 12 years.

- Zone 1. Weakened spruce forest with sparsely growing trees, higher proportion of birches (10-20\%), and ground cover reduced to 80 $90 \%$; the longevity of spruce needles 6 to 9 years; birch leaves without necrotic damage by the end of the growth season.

- Zone 2. Very sparse birch-dominated forest with dense birch growlings and saplings ( 1500 6000 per ha), sometimes with young pine trees; vegetation cover 40-60\%; the longevity of spruce needles $<4-5$ years, birch leaves with necrotic spots by the end of the growth season.

- Zone 3. Depressed birch woodland, with tree height $<2 \mathrm{~m}$; birch foliage heavily injured already in mid-July; ground vegetation almost vanished (cover 5-15\%), soils eroded and bedrock open in large areas.

Table 1. Basic characteristics of the study sites.

\begin{tabular}{|c|c|c|c|c|c|c|c|}
\hline $\begin{array}{l}\text { Distance from } \\
\text { smelter }(\mathrm{km})\end{array}$ & $\begin{array}{l}\text { Direction } \\
\text { from smelter }\end{array}$ & $\begin{array}{c}\text { Annual } \mathrm{SO}_{2} \\
\text { level }\left(\mu \mathrm{g} / \mathrm{m}^{3}\right)^{\mathrm{a}}\end{array}$ & $\frac{\text { Plant species }}{\text { Vascular }}$ & $\frac{\text { per } 100 \mathrm{~m}^{2}}{\text { Total }^{\mathrm{b}}}$ & $\begin{array}{c}\text { Total cover } \\
(\%)^{\mathrm{b}}\end{array}$ & Zone & $\begin{array}{c}\text { Total sampling } \\
\text { effort (counts) }\end{array}$ \\
\hline 13 & North & 20 & 7 & 12 & 40 & 2 & 48 \\
\hline 10 & North & 25 & 6 & 8 & 25 & 2 & 32 \\
\hline 7 & North & 120 & 6 & 7 & 15 & 3 & 28 \\
\hline 1 & North & 1000 & 5 & 5 & 25 & 4 & 32 \\
\hline 1 & South & 800 & 8 & 8 & 50 & 4 & 40 \\
\hline 5 & South & 450 & 6 & 8 & 30 & 3 & 72 \\
\hline 9 & South & 400 & 6 & 7 & 10 & 3 & 88 \\
\hline 16 & South & 55 & 8 & 10 & 50 & 2 & 80 \\
\hline 23 & South & 40 & 11 & 13 & 80 & 2 & 84 \\
\hline 29 & South & 30 & 7 & 14 & 90 & 1 & 128 \\
\hline 35 & South & 15 & 7 & 14 & 95 & 1 & 24 \\
\hline 65 & South & 5 & 6 & 13 & 95 & 0 & 40 \\
\hline
\end{tabular}

aAfter Baklanov and Rodjushkina 1993, Barkan 1993, Kryuchkov 1993.

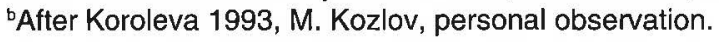


- Zone 4. Similar to 3, but with large willow bushes (Salix caprea, S. borealis) and spots of ruderal vegetation (Urica dioica, Epilobium angustifolium) formed on barrenlands adjacent to the smelter.

\subsection{Transect counts}

Four lines of $100 \mathrm{~m}$, forming a quadrate or circle, were marked at each sampling site. Counts were conducted 1-29 July 1991, 27 June-27 July 1992 and 11-22 July 1993. Limits of weather conditions were followed according to Pollard (1977), with modifications for the northern areas as published by Somerma and Väisänen (1990). Meteorological data were recorded at the beginning of each count. The ambient air temperature was measured by thermometer and wind strength was estimated according to the Beaufort scale. Degree of cloudiness (ranked as $0,25,50,75$ or $100 \%$ ) and the presence of shade were also recorded. These data were used to test the hypothesis that among-site differences were related to variable weather conditions at the time of the counts.

The observer walked along the transect route with an even speed and counted all butterflies and moths sighted within $5 \mathrm{~m}$ either side of the $100-\mathrm{m}$ line. Stops were made for identification purposes, but no specimens were collected at the study sites. Each line took $<5$ minutes to count. To minimize the error caused by daily rhythms of activity, every second site was visited between 10 a.m. and 2 p.m., other sites between 2 and 6 p.m. The sites visited in the first half of the day were next time counted during the second half of the day.

\subsection{Treatment of data}

The relationship between the site-specific densities of the monitored species and the mean annual $\mathrm{SO}_{2}$ concentrations were investigated by using the Spearman rank correlation coefficient (CORR procedure, SAS Institute 1990). To account for a possible non-linear response, the density variation was tested by SAS NPARIWAY procedure with vegetation zones as an independent variable. Since sampling design might be unbalanced in respect of observation time and weather condi- tions, least-square means (LSMs) were computed for each plot and compared with corresponding mean values. LSMs are estimators of the plot marginal means that would be expected had the design been balanced (SAS Institute 1990). Pairwise comparisons between mean values were based on $t$-test with the confidence limit $\mathrm{P}=0.05$.

\section{Results}

\subsection{Species composition}

During the three years of observation, 671 individuals comprising 19 species were observed (Table 2). Five species were commonly encountered, including three day-active moths, Rheumaptera subhastata, Ematurga atomaria and Sympistis heliophila, and two butterfly species, Vacciniina optilete and Clossiana euphrosyne. Together, these five species accounted for $93.1 \%$ of total observations; $R$. subhastata, the most abundant species, comprised $35.6 \%$ of observations.

The maximum number of species was recorded in the vegetation zones 1 and 2 (Table 2). Both mean abundance of Lepidoptera and total number of species counted on transect lines correlated with the total number of plant species (including mosses and lichens) per $100 \mathrm{~m}^{2}\left(\mathrm{r}_{\mathrm{s}}=0.82\right.$ and $r_{s}=0.76, n=12, P<0.01$, respectively). The number of vascular plant species and the vegetation cover (Table 1 ) have lower explanatory values $\left(r_{S}=0.46-0.64\right)$.

\subsection{Population densities}

Population densities of the five most abundant species peaked in localities with moderate (15$40 \mu \mathrm{g} / \mathrm{m}^{3}$ ) concentrations of sulphur dioxide (Figs. $1-5)$. The maximum densities were 1.5 to 5 times higher than densities in the site with $\mathrm{SO}_{2}$ concentration close to the background level $\left(5 \mu \mathrm{g} / \mathrm{m}^{3}\right)$, depending on species. The density variation in respect to both study site (Table 3 ) and vegetation rank (Figs. 6-10) was highly significant for all species $\left(\mathrm{F}_{4,723}=4.7-14.5, \mathrm{P}<0.001\right)$.

Although individual counts were greatly affected by the observation time and weather conditions (Table 3), the site-specific LSMs (least- 
square means) of all species except for R. subhastata correlated with the corresponding mean values $(\mathrm{r}=0.90-0.99, \mathrm{n}=12, \mathrm{P}<0.0001)$; for $R$. subhastata this correlation was only marginally significant $(\mathrm{r}=0.53, \mathrm{n}=12, \mathrm{P}<0.063)$. The high correlations between means and LSMs indicated that the experimental design has been well balanced, and therefore the differences between study sites could be attributed to the environmental heterogeneity.

Table 2. Species of butterflies and day-active moths observed at different distances from the smelter (cf. Table 1). Data represent the total number of individuals observed at each site.

\begin{tabular}{|c|c|c|c|c|c|c|c|c|c|c|c|c|c|}
\hline & \multirow{3}{*}{$\begin{array}{l}\text { Total no. of } \\
\text { specimens }\end{array}$} & \multicolumn{10}{|c|}{ Distance from the smelter $(\mathrm{km})$} & \multirow[b]{3}{*}{35} & \multirow[b]{3}{*}{65} \\
\hline & & \multicolumn{4}{|c|}{ Northwards } & \multicolumn{6}{|c|}{ Southwards } & & \\
\hline & & 13 & 10 & 7 & 1 & 1 & 5 & 9 & 16 & 23 & 29 & & \\
\hline \multicolumn{14}{|l|}{ Pieridae } \\
\hline Pieris napi (L.) & 6 & 0 & 0 & 0 & 1 & 5 & 0 & 0 & 0 & 0 & 0 & 0 & 0 \\
\hline Colias palaeno (L.) & 3 & 1 & 0 & 0 & 0 & 0 & 0 & 0 & 0 & 2 & 0 & 0 & 0 \\
\hline \multicolumn{14}{|l|}{ Lycaenidae } \\
\hline Callophrys rubi (L.) & 1 & 0 & 0 & 0 & 0 & 0 & 0 & 0 & 0 & 0 & 1 & 0 & 0 \\
\hline Lycaeides idas (L.) & 14 & 5 & 3 & 0 & 0 & 0 & 0 & 0 & 1 & 0 & 3 & 0 & 2 \\
\hline Vacciniina optilete (Knoch) & 89 & 5 & 3 & 0 & 0 & 0 & 8 & 4 & 7 & 26 & 25 & 5 & 6 \\
\hline Polyommatus icarus (Rott.) & 1 & 0 & 0 & 0 & 0 & 1 & 0 & 0 & 0 & 0 & 0 & 0 & 0 \\
\hline \multicolumn{14}{|l|}{ Nymphalidae } \\
\hline Boloria aquilonaris (Stich.) & 4 & 0 & 0 & 0 & 0 & 0 & 0 & 0 & 0 & 0 & 4 & 0 & 0 \\
\hline Proclossiana eunomia (Esp.) & 1 & 0 & 0 & 0 & 0 & 0 & 0 & 0 & 0 & 0 & 1 & 0 & 0 \\
\hline Clossiana selene (D. \& S.) & 2 & 0 & 0 & 0 & 0 & 0 & 0 & 0 & 0 & 1 & 1 & 0 & 0 \\
\hline Clossiana freija (Thunb.) & 3 & 0 & 0 & 0 & 0 & 0 & 0 & 0 & 0 & 1 & 2 & 0 & 0 \\
\hline Clossiana frigga (Thunb.) & 3 & 0 & 0 & 0 & 0 & 0 & 0 & 0 & 0 & 0 & 3 & 0 & 0 \\
\hline Clossiana euphrosyne (L.) & 98 & 3 & 6 & 0 & 0 & 0 & 0 & 1 & 13 & 22 & 50 & 3 & 0 \\
\hline \multicolumn{14}{|l|}{ Satyridae } \\
\hline Erebia disa (Thunb.) & 2 & 0 & 0 & 0 & 0 & 0 & 0 & 0 & 0 & 1 & 1 & 0 & 0 \\
\hline Erebia pandrose (Bkh.) & 2 & 0 & 0 & 0 & 0 & 0 & 0 & 0 & 0 & 2 & 0 & 0 & 0 \\
\hline Oeneis norna (Thunb.) & 3 & 1 & 0 & 0 & 0 & 0 & 0 & 0 & 0 & 1 & 0 & 1 & 0 \\
\hline Coenonympha tullia (Müll.) & 1 & 0 & 0 & 0 & 0 & 0 & 0 & 0 & 0 & 1 & 0 & 0 & 0 \\
\hline \multicolumn{14}{|l|}{ Geometridae } \\
\hline Rheumaptera subhastata (Nolck.) & .) 237 & 10 & 1 & 2 & 0 & 0 & 15 & 6 & 23 & 48 & 109 & 9 & 14 \\
\hline Ematurga atomaria (L.) & 106 & 14 & 5 & 4 & 0 & 1 & 5 & 12 & 47 & 3 & 3 & 6 & 0 \\
\hline \multicolumn{14}{|l|}{ Noctuidae } \\
\hline Sympistis heliophila (Payk) & 95 & 9 & 5 & 3 & 0 & 0 & 6 & 7 & 9 & 38 & 13 & 1 & 4 \\
\hline
\end{tabular}

Table 3. Effects of experimental design and weather conditions ( $F$ values and confidence limits) on the abundance of the monitored species. Probability levels: ${ }^{\star \star \star} P<0.001,{ }^{\star \star} P<0.01,{ }^{\star} P<0.05$.

\begin{tabular}{lccccc}
\hline Variation source & $\begin{array}{c}\text { Clossiana } \\
\text { euphrosyne }\end{array}$ & $\begin{array}{c}\text { Vacciniina } \\
\text { optilete }\end{array}$ & $\begin{array}{c}\text { Rheumaptera } \\
\text { subhastata }\end{array}$ & $\begin{array}{c}\text { Ematurga } \\
\text { atomaria }\end{array}$ & $\begin{array}{c}\text { Sympistis } \\
\text { heliophila }\end{array}$ \\
\hline Locality & $5.75^{\star \star \star}$ & $3.84^{\star \star \star}$ & $4.76^{\star \star \star}$ & $4.34^{\star \star \star}$ & $8.53^{\star \star \star}$ \\
Year & $14.28^{\star \star \star}$ & 0.07 & $74.73^{\star \star \star}$ & $10.93^{\star \star \star}$ & $5.87^{\star}$ \\
Date & 0.01 & 0.09 & 0.34 & 0.03 & $7.27^{\star \star}$ \\
Time & 0.92 & 0.30 & $26.84^{\star \star \star}$ & 0.18 & 0.22 \\
Temperature & 0.53 & 0.66 & $40.42^{\star \star \star}$ & $7.04^{\star \star}$ & 1.17 \\
Wind & 0.03 & $6.24^{\star}$ & $21.03^{\star \star \star}$ & 0.00 & $10.09^{\star \star}$ \\
Shade (yes/no) & $5.61^{*}$ & $9.24^{\star \star}$ & 0.37 & 0.22 & 0.20 \\
Cloudiness & $4.48^{\star}$ & 2.17 & $17.73^{\star \star \star}$ & 1.72 & $9.90^{\star \star}$ \\
\hline
\end{tabular}



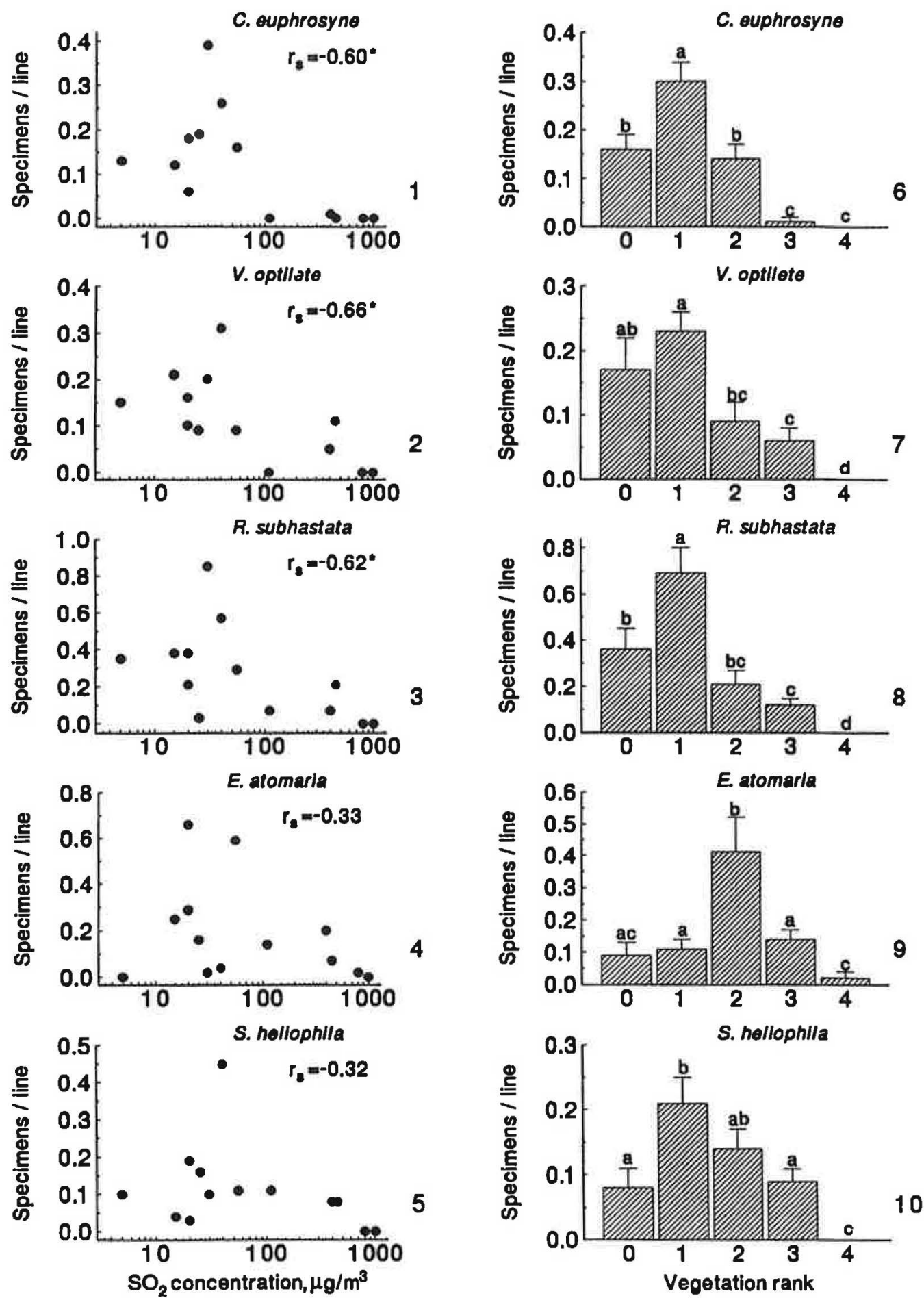

Figs. 1-10. Densities of the monitored species (specimens per transect line). 1-5: the site-specific means plotted against mean annual concentrations of sulphur dioxide. 6-10: the zone-specific means and standard errors; differences between bars marked with different letters are significant $(P<0.05)$. 
Clossiana euphrosyne (Fig. 6) was equally abundant in unpolluted (zone 0 ) and moderately polluted (zone 2) sites, with peak density attained at early stages of pollution-induced forest deterioration (zone 1). In this species, population decline near the smelter was probably related to the decline of host plants (Viola) which are strongly associated with forests and were not discovered in birch woodlands and barrenlands.

Vacciniina optilete (Fig. 7) showed similar abundance in spruce-dominated forests (zones 0 and 1), while in birch forests and woodlands (zones 2 and 3 ) the densities were 30 to $50 \%$ of the density in the unpolluted site. This species was never recorded in the barrenlands (zone 4) where the host plant (Vaccinium uliginosum) was as abundant as in zones 2 and 3 (Koroleva 1993).

Rheumaptera subhastata (Fig. 8) showed a density pattern similar to C. euphrosyne, with the maximum abundance in the slightly weakened (zone 1) spruce forests. The peak density was twice as high as in the unpolluted plot. But the density of $R$. subhastata in the depressed birch woodlands (zone 3 ) was about $30 \%$ of the background level, while C. euphrosyne has practically vanished there. The host plants of $R$. subhastata, Vaccinium myrtillus and V. uliginosum, were recorded in all habitats, with maximum density in unpolluted forest (zone 0) (Koroleva 1993).

Ematurga atomaria (Fig. 9) was the only species the density of which peaked in the birch transitional community (zone 2). In all other habitats, including barrenlands, this species was almost equally abundant. The density changes matched well with the abundance of the host plant (Calluna) which also attained its maximum level in zone 2 (Koroleva 1993).

Sympistis heliophila (Fig. 10) peaked in slightly damaged forests (zone 1) and declined toward industrial barrens, although the host plant (Empetrum nigrum) was relatively abundant even in the most destroyed habitats (Koroleva 1993).

\section{Discussion}

\subsection{Spatial trends in population densities}

Industrial pollution can radically change densities of insects (for recent reviews, see Riemer \&
Whittaker 1989, Kozlov 1990a, Heliövaara \& Väisänen 1993). Among Lepidoptera, an increase in ecological density (i.e. specimens per food supply) in heavily and/or moderately polluted areas seems to be a typical case (Kozlov 1990b), explained by the beneficial changes in the host plant quality (Koricheva \& Haukioja 1992, Kozlov et al. 1996b). Our data showed that the abundance of butterflies and day-active moths followed the same pattern, although the peak densities, like in Noctuidae (Kozlov et al. 1996a) corresponded to much lower pollution loads than in the birch-feeding microlepidopterans (Kozlov 1985 and personal observations). In contrast to miners and leafrollers, which are more or less protected from acid rains, the direct negative effects of acidification on leaf-chewers may exceed positive changes in the host plant quality (Kozlov et al. 1996b).

The autochthonous fauna of butterflies and day-flying moths has almost entirely vanished within a radius of about $10 \mathrm{~km}$ from the emission source, where the annual mean concentration of sulphur dioxide exceeds $100 \mu \mathrm{g} / \mathrm{m}^{3}$. Beyond that, there is a zone of decline which (at least for some species) is not caused by the lack of host plants. Most of these plant species occurred even in the immediate vicinity of the smelter, although they generally were less abundant than in undisturbed forests. These results confirm the conclusion by Barbour (1986) who reported a decline of butterfly populations in areas with annual $\mathrm{SO}_{2}$ concentrations around $60 \mu \mathrm{g} / \mathrm{m}^{3}$. Thus, day-active macrolepidopterans seem to be more sensitive to pollution than Noctuidae (cf. Kozlov et al. 1996a) and microlepidoptera in general (cf. Kozlov 1995).

The actual reasons for the decline of the monitored species are uncertain, but the effect is most probably connected with $\mathrm{SO}_{2}$ impact either on insects or their habitats or both. However, the level of habitat deterioration is determined by the pollution load, and these two possible causes of decline can not be separated in our study.

We presume that sulphur dioxide rather than heavy metals is the causal factor behind the decline of the moth populations. The foliar concentrations of the main metal pollutants, nickel and copper, recorded for various plants growing near the smelter generally did not exceed $300 \mathrm{mg} / \mathrm{kg}$ (Kataev et al. 1994, Kozlov et al. 1995, Zvereva et al. 1995ab) which is below the toxicity limits 
for terrestrial insects (Butovsky \& Roslavtseva 1989, Boyd \& Martens 1994). Furthermore, no effects of foliar metals on leaf beetle or leafminer performance was revealed (Zvereva et al. 1995ab; Kozlov \& Haukioja, personal observations). Correlations between metal concentrations and insect abundance/performance repeatedly reported in field measurements (revicwed by Heliövaara \& Väisänen 1993) could not advocate for a causal relationship: distribution patterns of various pollutants are similar, and correlation between the concentrations of metals and $\mathrm{SO}_{2}$ may approach 0.99 (Barkan 1993). In contrast, direct toxicity of $\mathrm{SO}_{2}$ concentrations which mimic the levels observed around the Severonikel smelter (cf. Barkan 1993, Kryuchkov 1993) has been demonstrated by means of fumigation experiments (Whittaker \& Warrington 1990, Kozlov et al. 1996b).

\subsection{Environmental assessment using data on Lepidoptera}

The practical application of the transect counts to monitor populations of subarctic Lepidoptera seems less profitable than in more southern regions, because the low abundance of butterflies and moths may not provide sufficient data for the analysis. Furthermore, all species are very sensitive to meteorological conditions which creates additional problems in the planning of sampling design and in the treatment of the data. Among the five monitored species, $C$. euphrosyne and $R$. subhastata are most profitable because they demonstrated a relatively low sensitivity to weather conditions and a high density variation in respect to pollution loads.

Although in an earlier study (Kremen 1992) the butterflies were shown to be poor indicators of heterogeneity caused by anthropogenic disturbances, we found that transect counts did produce valuable information about the impact of pollution on subarctic forest ecosystems. The most important conclusion is that all monitored species are highly sensitive to low pollution loads. At early stages of pollution-induced forest damage, which are not easy to monitor, the population densities increased by the factor of 1.5 to 5 . At higher pollution loads the numbers of day-active lepidopterans declined.
Acknowledgements. We thank E. Halme, J. Jalava and $\mathrm{N}$. Koroleva for their assistance in the collecting of data, S. Neuvonen for statistical advice, E. Haukioja, J. Vranjic and two anonymous referees for the valuable comments on the early drafts of the manuscript and improving of the language. The study was supported by the Academy of Finland through a grant to Kauri Mikkola.

\section{References}

Baklanov, A. \& Rodjushkina, I. A. 1993: Pollution of ambient air by "Severonikel" smelter complex: observations and modelling. - In: Kozlov, M. V., Haukioja, E. \& Yarmishko, V. T. (eds.), Aerial pollution in Kola Peninsula: Proc. Intern. Workshop, April 14-16 1992, St. Petersburg. Apatity: 83-89.

Barbour, D. A. 1986: Why are there so few butterflies in Liverpool? An answer. - Antenna 10(2) : 72-75.

Barkan, V. Sh. 1993: Measurement of atmospheric concentrations of sulphur dioxide by passive lead dioxide absorbers. - In: Kozlov, M. V., Haukioja, E. \& Yarmishko, V. T. (eds.), Aerial pollution in Kola Peninsula: Proc. Intern. Workshop, April 14-16 1992, St. Petersburg. Apatity: 90-98.

Berlyand, M. Е. (Берлянд, М. Е.) (ed.) 1991: [Annual report on ambient air pollution in cities and industrial centres of Soviet Union. Volume "Emission of pollutants: 1990".] - Voeikov Main Geophysical Observatory, St. Peterburg. (In Russian.)

Boyd, R. S. \& Martens, S. N. 1994: Nickel hyperaccumulated by Thlaspi montanum var. montanum is acutely toxic to an insect herbivore. - Oikos 70: 21-25.

Butovsky, R. O. \& Roslavtseva, S. А. (Бутовский, Р. O. \& Рославцева, С. А.) 1989: [Repellency and toxicity of heavy metal salts for insects.] - Agrokhimija [Agrochemistry, Moscow] (1) : 109-114 (in Russian).

Hall, M. E. 1981: Butterfly monitoring scheme. Instructions for independent recorders. - Institute of Terrestrial Ecology, Abbots Ripton, Huntington. 14 pp.

Heliövaara, K. \& Väisänen, R. 1993: Insects and pollution. - CRC Press, Boca Raton. 393 pp.

Kataev, G. D., Suomela, J. \& Palokangas, P. 1994: Densities of microtine rodents along a pollution gradient from a copper-nickel smelter. - Oecologia 97: 491-498.

Koricheva, J. \& Haukioja, E. 1992: Effects of air pollution on host plant quality, individual performance, and population density of Eriocrania miners (Lepidoptera: Eriocraniidae). - Environ. Entomol. 21: 1286-1292.

Koroleva, N. 1993: Pollution-induced changes in forest vegetation structure as revealed by ordination test. In: Kozlov, M. V., Haukioja, E. \& Yarmishko, V. T. (eds.), Aerial pollution in Kola Peninsula: Proc. Intern. Workshop, April 14-16 1992, St. Petersburg. Apatity: 339-345.

Kozlov, M. V. (Козлов, М. В.) 1985: [Changes in phytophagous insect communities affected by airborne pollutants near the non-ferrous smelter.] — In: Kastrel, T. N. 
(Кастрель, Т. Н.) (ed.), [Problems of Biosphere (Information Bulletin)], no. 11, Scientific Board on Biospheric Problems, Academy of Sciences, Moscow: 76-90. (In Russian.)

Kozlov, M. V. (Козлов, М. В.) 1990a: [Impact of anthropogene factors on the populations of terrestrial insects.] - All-Union Institute of Scientific and Technical Information (VINITI), Moscow. 192 pp. (In Russian.)

Kozlov, M. V. (Козлов, М. В.) 1990b: The ecology of Lepidoptera in forests suffering from air pollution. - In: XIX IUFRO World Congress, 5-11, August 1990, Montréal, Canada, Proceedings, Div. 2: 151. Oxford.

Kozlov, M. V. (Козлов, М. В.) 1995: Subalpine and alpine assemblages of Lepidoptera in the surroundings of a powerful smelter on the Kola Peninsula, NW Russia. - Nota lepidopterologica 18: 17-37.

Kozlov, M. V. \& Haukioja, E. 1995: Pollution-related environmental gradients around the "Severonikel" smelter complex at the Kola Peninsula, Northwestern Russia. - In: Munawar, M. \& Luotola, M. (eds.), The contaminants in the nordic ecosystem: the dynamics, processes and fate. Ecovision World Monograph Series, S. P. B. Academic Publ., The Netherlands: 59-69.

Kozlov, M. V., Haukioja, E., Bakhtiarov, A. V. \& Stroganov, D. N. 1995: Heavy metals in birch leaves around a nickel-copper smelter at Monchegorsk, Northwestern Russia. — Environ. Pollut. 90: 291-299.

Kozlov, M. V., Jalava, J., Lvovsky, A. L. \& Mikkola, K. 1996a: Population densities and diversity of Noctuidae (Lepidoptera) along an air pollution gradient on the Kola Peninsula, Russia. - Entomol. Fenn. 7: 9-15.

Kozlov, M. V., Zvereva, E. L. \& Selikhovkin, A. V. 1996b: Decreased performance of Melasoma lapponica (Coleoptera: Chrysomelidae) fumigated by sulphur dioxide: direct toxicity versus host plant quality. - Environ. Entomol. 25: 143-146.

Kremen, C. 1992: Assessing the indicator properties of species assemblages for natural areas monitoring. - Ecol. Applications 2: 203-217.

Kryuchkov, V. V. 1993: Degradation of ecosystems around the "Severonikel" smelter complex. - In: Kozlov, M. V., Haukioja, E. \& Yarmishko, V. T. (eds.), Aerial pollution in Kola Peninsula: Proc. Intern. Workshop, April 14-16 1992, St. Petersburg. Apatity: 35-46.

Pollard, E. 1977: A method for assessing changes in the abundance of butterflies. - Biol. Conserv. 12: 115-134.

Pollard, E. 1991: Monitoring butterfly numbers. - In: Goldsmith, B. (ed.), Monitoring for conservation and ecology. Chapman \& Hall, London, NY: 87-111.

Pollard, E., Hall, M. L. \& Bibby, T. J. 1986: Monitoring the abundance of butterflies, 1976-85. - Research and Survey in Nature Conservation, 2, Nature Conservancy Council, Peterborough.

Pollard, E., Van Swaay, C. A. M. \& Yates, T. J. 1993: Changes in butterfly numbers in Britain and The Netherlands, 1990-91. — Ecol. Entomol. 18: 93-94.

Riemer, J. \& Whittaker, J. B. 1989: Air pollution and insect herbivores: observed interactions and possible mechanisms. - In: Bernays, E. A. (ed.), Insect-Plant interactions. CRC-press, Boca Raton, Florida: 73-105.

SAS Institute 1990: SAS/Stat. User's guide, version 6.0. SAS Institute, Cary, N.C.

Somerma, P. \& Väisänen, R. 1990: Luonnonsuojelualueiden perusselvitykset: perhoset. - Baptria 15: 77-101.

Väisänen, R. 1992: Distribution and abundance of diurnal Lepidoptera on a raised bog in southem Finland. Ann. Zool. Fennici 29: 75-92.

Whittaker, J. B. \& Warrington, S. 1990: Effects of atmospheric pollutants on interactions between insects and their food plants. - In: Burdon, J. J. \& Leather, S. R. (eds.), Pests, pathogens and plant communities. Blackwell, Oxford: $97-110$.

Zvereva, E., Kozlov, M. V. \& Neuvonen, S. 1995a: Population density and performance of Melasoma lapponica (Coleoptera: Chrysomelidae) in surroundings of smelter complex. - Environ. Entomol. 24: 707-715.

Zvereva, E. L., Kozlov, M. V. \& Neuvonen, S. 1995b: Decrease in feeding niche breadth of Melasoma lapponica (Coleoptera: Chrysomelidae) with increase in pollution. — Oecologia 104: 323-329. 